vezetői üzleti gazdaságtan az események rögzítésén túlmenően fontos szerephez jut a működési és stratégiai döntések meghozatalában, a szervezeti teljesítmény értékelésében, az ösztönzések kialakításában s így jelentős erőforrássá válik. A könyv valamennyi fejezete végén számos feladatot, kérdést, vállalati esettanulmányt találunk. Ezek az olvasókat gondolkodásra késztetik és számszerüen, a vállalatok mindennapi életéből vett példákkal világítják meg a könyvben leírt elméleti ismeretek gyakorlati alkalmazását.

R. I.

Görög Mihály

A

PROJEKTVEZETÉS MESTERSÉGE

\section{Aula Kiadó,}

Budapest, 2003. 376 p.

A szervezet számára komplex feladatot jelentő projektek meghatározott eredmények létrehozására irányulnak. Az elmúlt évszázad utolsó negyedében bekövetkezett nagyarányú változások a szervezeteknél a megindított projektek számának a növekedésével jártak; alaposan megnőtt a projektvezetés eszköztára is. Felismerték, hogy a projektvezetési folyamatot lényegesen befolyásolják a környezeti sajátosságok, és ezek hatással vannak az eszközök alkalmazására is. Kialakult a projektek vezetéséhez szükséges szemléletmód, valamint a projektvezetési eszköztár ismeretének, alkalmazásának és döntéshozatalának a tudománya is: a projektvezetési mesterség. A szerző ebben a tárgykörben korábban megjelent könyveiben (Bevezetés a projektmenedzsment- be, Általános projektmenedzsment) a projektvezetési eszközök megismertetésével és a stratégiaorientált projektmenedzsment kialakításával foglalkozott. Most megjelent munkája ezekhez kapcsolódva a projektvezetési mesterség tudományos megalapozottságának a javítási lehetőségeit, a stratégiával kialakítandó összhang megteremtését és az eszköztár alkalmazásának elméleti-módszertani alapjait mutatja be a különböző és változó szervezeti környezetben.

A projektek - mint a szervezeti stratégia megvalósításának építőelemei - céljuk szerint beruházási, kutatási, szervezetfejlesztési projektek lehetnek. A projektekért felelős vezetők felkészültsége fontos szerepet játszik a siker elérésében. A projektvezetési képességek technikai, humán és projektspecifikus vezetési képességekből állnak. Az utóbbi a folyamat irányításának, az eszközök ismeretének a tudását - a projektvezetés mesterségét - jelenti. Az eszközök: a projektvezetési technikák, módszerek és eljárások. Az ismereteken és alkalmazási készségeken túlmenően projektvezetési szemléletmódra is szükség van, amely a stratégiák és a projektek összefüggésének stratégiaorientált szemlélete. Az ezzel foglalkozó 4. fejezet a projektfolyamat szereplöit, alapvető sajátosságait, a szervezetekhez illeszkedő alkalmazását mutatja be. Szó van itt még a bizonytalansági tényezőkről és a projektfolyamatra jellemző, az egyes projekttevékenységek közötti kölcsönös függésről (interdependencia) is.

A következőkben a projektvezetési eszközöket és alkalmazásukat, a projekteredmény megfelelő behatárolása során a megvalósíthatósági tanulmányok szerepét ismerjük meg. A szerző áttekinti az idő-, erőforrás- és költségtervezés kér- déseit, az alkalmazási lehetőségeket, a kiválasztást meghatározó körülményeket. A bizonytalanság miatt számolni kell a kockázatokkal is, olvashatunk értékelésükről és kezelésükről. A kockázatkezelés segít abban, hogy hatásuk számszerűsíthetô és alakítható legyen. A projektszervezeti formák bemutatása után azok kiválasztásának szempontjai, a szervezeti megoldások kialakítása, alkalmazásuk kerülnek tárgyalásra. Áttekintést kapunk a projektkontroll folyamatáról, eszközrendszeréről, amelyet a sikeresség, az eredménykontrollt pedig a szervezeti környezet sajátosságai határozzák meg.

A projektteljesítési stratégia eszköztáráról és döntésmódszertanáról szóló (10.) fejezetben az erre szolgáló eszközöket - szerződéstípusokat, pénzügyi elszámolási módokat - ismerjük meg, majd esetpéldát találunk a projektteljesítési stratégia kialakítására. Ezután a versenyeztetés típusainak, az előzetes minősítésnek, értékelésnek a bemutatása, valamint az ajánlati felhívástól a szerződés életbe lépéséig elvégzendő feladatok leírása következik.

A projektmarketing egyrészt abból áll, hogy a projekttulajdonos igyekszik a projektet elfogadhatóvá tenni az érintett érdekcsoportok számára; tehát mint piaci tevékenység, az érintetteknek a megelégedettségére törekszik. Másrészt a közreműködői marketingtevékenység középpontjában az eredmény létrehozásának a képessége - a projektfeladat teljesítése - áll; az eredmény létrehozásában a vevő maga is aktívan részt vesz. A projektvezetési eljárások keretében alkalmazásuk előnyeiről és hátrányairól olvashatunk, amelyekre a szervezeti környezet és a siker követelménye egyaránt hatással van. A szerző részletesen bemutatja a PRINCE projektvezetési eljárást. 
A projekteredmény a használatbavétel után a szervezet napi múködésének a része lesz, $s$ teljesíti a stratégiában kijelölt feladatokat. A használatbavételt a működési próba és az utóelemzés követi. A projektzárás feladataiért rendszerint a projektvezető a felelős; a zárás az összefoglaló jelentés elkészítésével és a projektzáró értekezlettel fejeződik be. Végül a szerző áttekinti a projekt sikeres teljesítéséhez szükséges (technikai, jogi, vezetési) dokumentumokat, megjelölve azok célját, lényegét. Formai követelményeit és a köztük lévő összefüggéseket. Megismerjük a projektvezetést közvetlenül támogató számítógépes programcsomagok alkalmazásának lehetőségeit, alkalmazásuk szempontjait is. A szerző beszámol a projektvezetési ismeretek standardizálására irányuló törekvésekről, majd arról szól, hogy hogyan javítható a projektvezetési mesterség tudományos megalapozottsága.

A projektvezetés eszköztárának sikeres gyakorlati alkalmazását és annak elméleti-módszertani lapjait - a szerző saját kutatási eredményeinek a felhasználásával - bemutató könyvet Fogalomtár és Irodalomjegyzék egészíti ki.

R. I.

\section{Vigvári András}

\section{PÉNZÜGY/ RENDSZER/TAN}

\section{KJK-KERSZÖV \\ Jogi és Üzleti Kiadó Kft., Budapest, 2004. 336 p.}

A közgazdaságtudományok közé tartozó pénzügytan a pénz-ügyi rendszerek működését és azoknak a gazdaságra gyakorolt hatásait vizsgálja. A pénzügyi rendszer fejlődésével foglalkozó pénzügy- $\tan$ az egyik legdinamikusabban korszerúsödő tudományág; jelentős helyet foglal el a felsőoktatásban is. A gazdaság részét képező pénzügyi rendszer kialakulása hosszú fejlődési folyamat eredménye, hatással van a többi társadalmi alrendszerre (politika, kultúra, technológia) is. Funkciói sokfélék: a gazdaság pénzellátásának a biztosítása, a megtakarításoknak a beruházókhoz történő továbbítása, a bizonytalanságok és a kockázatok kezelése, gazdaságpolitikai funkciók stb. A könyv szerzője átfogó ismereteket kíván nyújtani a mai gazdaságban központi szerepet betöltő pénzügyi rendszer folyamatairól, szereplőiről, a monetáris és fiskális rendszer működéséről, az információ jelentőségéről stb. Rámutat arra, hogy a rendszerelméleti megközelítés szorosan kapcsolódik a történeti tárgyalásmódhoz, mert a pénzügyi rendszer is folyamatosan változik. Az újszerű tárgyalásmódban közreadott ismeretek elsősorban az egyetemi oktatásban résztvevốk számára készültek; a közgazdaságtant tanulókon kívül a könyv a mérnök, a jogász, a történész hallgatók és a pénzügyek iránt érdeklődő olvasók számára egyaránt ajánlható. A leírtak jobb megértését ábrák és táblázatok, illusztrációk és mátrixok stb. segítik.

A pénz fogalmának meghatározása során kifejti a szerző, hogy a pénz társadalmi intézmény s ezért a társadalom fejlődésével a pénz, a pénzrendszer is változik. Megjelenése, működése szorosan összefügg a gazdasági fejlődéssel, azzal együtt a pénz funkciói is fejlődtek. Alapvetố funkciói: a gazdasági elszámolások, a különféle gazdasági tranzakciók lebonyolításának az eszköze és a vagyontartás egyik eszköze is. Az ún. világpénz nem önálló funkció, hanem arra utal, hogy egyes pénzek, pénzrendszerek lokálisan, mások globálisan is betölthetik a pénzfunkciókat. A pénzügyi jog szerint a pénzrendszer az állam pénzforgalmának törvényes formája; a törvényes fizetőeszköz elfogadását az állam szavatolja. Kibocsátása állami monopólium. A pénzrendszer fogalmába így az állami szabályozás is beletartozik.

Az aranynak a pénzfunkciókból történő kiszorulása (demonetizálódása) összefüggött a tőkés piacgazdaság vegyes gazdasággá való átalakulásával. Nyilvánvalóvá vált, hogy egy belső értékkel nem rendelkező dolog (papírpénz) is betöltheti a pénz funkcióit. A továbbiakban megismerjük a mai pénzrendszereket (a bankszektor által biztosított hitelpénzrendszer), a pénz és a bizalom összefüggését, a pénznek a reálgazdaságra gyakorolt hatását, az infláció és a defláció lényegét, a pénzmennyiség és az infláció közti kapcsolatot, majd a szerző foglalkozik a pénz várható jövőjével, a nemzetközi fizetési forgalom felgyorsulásával is.

A monetáris rendszer a gazdaság vérkeringésének is nevezhetô. Intézményrendszere a kétszintű bankrendszer, amelynek felső szintjét a monetáris hatóság képezi, alsó szintjén pedig a kereskedelmi vagy betéti bankok és a nem monetáris pénzintézetek vannak. Megismerjük ezek funkcióit és feladatait, majd a pénzteremtố bankmúveletekről, a monetáris politika cél- és eszközrendszeréről, a jegybanki (személyi, működési, pénzügyi) függetlenségről olvashatunk a könyvben. Ismertetést kapunk a magyar belföldi fizetési rendszer főbb jellemzőiről is.

A pénzügyi piacok rendszere meghatározza a hitelek mennyiségét, a kamatlábat és az értékpapírok árfolyamát. A szerző bemutatja működését, a tökéletes piac modelljét, a hatékony piac fogal- 